\title{
APLIKASI AKUNTANSI UNTUK PERUSAHAAN DAGANG DENGAN FITUR KUSTOMISASI
}

\author{
Yulia $^{1}$, Felicia ${ }^{2}$, Andre Hariyanto Chandra, Rudy Adipranata ${ }^{3}$ \\ Teknik Informatika, Fakultas Teknologi Industri, Universitas Kristen Petra, Surabaya \\ E-mail : yulia@petra.ac.id ${ }^{1}$, felis@petra.ac.id², rudya@petra.ac.id ${ }^{3}$
}

\begin{abstract}
ABSTRAK: Di Indonesia banyak sekali terdapat perusahaan yang bergerak di bidang perdagangan tetapi sayang sekali untuk level menengah ke bawah banyak perusahaan tersebut masih menggunakan sistem manual guna menjalankan proses bisnisnya. Setiap hari terjadi sangat banyak transaksi yang dapat mengakibatkan ketidakefisien proses bisnis karena membutuhkan waktu lama untuk mendapatkan informasi yang diinginkan. Oleh karena itu dibutuhkan sistem informasi akuntansi yang memadai, untuk memproses pencatatan transaksi-transaksi yang terjadi secara komputerisasi dan menghasilkan informasi yang cepat dan tepat. Pembuatan sistem informasi akuntansi ini dimulai dengan survei proses bisnis yang umum terjadi di beberapa usaha dagang. Dari hasil yang diperoleh, dilakukan perancangan sistem informasi akuntansi yang dilengkapi dengan fitur kustomisasi yang diharapkan dapat digunakan di kebanyakan perusahaan dagang. Program aplikasi ini dapat memproses transaksi penjualan, pembelian, retur penjualan, retur pembelian, pembayaran hutang, pembayaran piutang, pembuatan laporan keuangan secara komputerisasi serta dilengkapi dengan fitur kustomisasi yang meliputi pemilihan metode persediaan, aliran biaya persediaan, dan periode akuntansi.
\end{abstract}

Kata kunci: aplikasi akuntansi, perusahaan dagang, fitur kustomisasi

\begin{abstract}
In Indonesia there are a lot of retail companies which purchase and sale goods without transforms the goods. But unfortunately for middle and low level companies, they still use manual system in their business. Because of the operational activities and business process of retail companies are very large and complex, the manual system can cause inefficiency in the system because need a lot of time to get information which is needed. Therefore an adequate accounting information system is needed to proceed, record the transactions and to produce information accurately and quickly. First step in building this accounting information system is to survey what general processes business are done in retail companies. And the second step is to design accounting information system which is attached with customization features and can be used in many retail companies. This application program can process sales, purchase, purchase return, sales return, payment of account payable, payment of account receivable, create accounting report, financial statement, and attached by customization features which consist of choosing inventory system methods, inventory cost flow methods, and accounting periods.
\end{abstract}

Keywords: accounting application, trading company, customized feature

\section{PENDAHULUAN}

Semua perusahaan baik jasa, dagang maupun manufaktur perlu melakukan pencatatan akuntansi untuk mengetahui kondisi keuangan usahanya. Karena dari laporan keuangan yang dihasilkan akan dapat menunjukkan keadaan keuangan perusahaan yang sesungguhnya, laba atau rugi. Permasalahan yang akan timbul apabila sistem akuntansi dilakukan secara manual adalah waktu yang banyak yang dibutuhkan untuk menghasilkan laporan keuangan selain itu tingkat keakurasiannya juga kurang. Padahal laporan keuangan ini kemudian dijadikan sebagai bahan evaluasi untuk mengambil strategi keuangan pada periode berikutnya sehingga usaha tersebut bisa tetap bertahan dan mengalami kemajuan.
Di antara tiga jenis usaha di atas, usaha dagang merupakan jenis perusahaan yang paling banyak ditemui di Indonesia mulai dari level kecil, menengah sampai besar. Selain itu juga proses bisnis dan sistem akuntansi dari usaha dagang yang satu dengan yang lain hampirlah sama. Oleh karena itu penelitian ini difokuskan untuk perusahaan yang bergerak di bidang dagang seperti toko, minimarket dan supermarket.

Sebenarnya telah banyak perangkat lunak (software) akuntansi yang dijual di pasaran baik dari luar dan dalam negeri. Tetapi ada beberapa kekurangan dari software-software tersebut, misalnya:

- Untuk software luar negeri/asing dijual dengan harga yang mahal yang tidak terjangkau, selain itu software tersebut memakai istilah-istilah akuntansi dalam bahasa asing sehingga akan sulit dimengerti 
oleh masyarakat terutama apabila yang menggunakan adalah badan usaha level kecil. Selain itu juga karena perbedaan mata uang, software tersebut mempunyai keterbatasan jumlah digit angka yang digunakan.

- Untuk software dalam negeri ada beberapa software yang penggunaannya kurang user friendly dan kurang fleksibel diimplementasikan untuk semua usaha dagang semua level.

Oleh karena itu, diperlukan suatu aplikasi akuntansi yang mampu mempermudah perusahaan dagang melakukan sistem akuntansi-nya. Aplikasi yang akan dibuat dalam penelitian ini dilengkapi dengan fitur kustomisasi sehingga memungkinkan usaha dagang semua level untuk menggunakannya. Aplikasi yang dihasilkan nantinya yang dapat di-setting sesuai dengan kebutuhan dan keinginan perusahaan saat awal pengimplementasiannya dengan fleksibel.

\section{SISTEM INFORMASI AKUNTANSI}

Akuntansi adalah proses yang tediri dari 3 aktivitas, yaitu identifikasi, merekam, dan mengkomunikasikan kejadian ekonomi pada sebuah organisasi [1]. Definisi sistem informasi akuntansi adalah memproses data dan transaksi untuk menyediakan informasi yang dibutuhkan oleh pemakai untuk perencanaan, pengendalian, dan pengoperasian bisnis [2]. Untuk menghasilkan informasi yang dibutuhkan untuk pengambil keputusan, maka sistem informasi akuntansi harus dapat mengumpulkan transaksi dan data lain dan memasukkannya ke dalam sistem tersebut, dapat memproses dan menyimpan data tersebut untuk masa yang akan datang, dan menyediakan informasi yang dibutuhkan oleh pemakai berupa laporan yang menghasilkan informasi yang akurat, tepat dan dapat diandalkan.

\section{Persamaan Akuntansi}

Menurut persamaan akuntansi, harta perusahaan pada dasarnya merupakan hak dari pihak lain yang dalam hal ini termasuk pemilik perusahaan. Selain menggunakan modal dari pemilik, juga menggunakan pinjaman untuk membiayai operasinya. Karena konsep kesatuan usaha menghendaki pemisahan modal pemilik dari kekayaan atau harta perusahaan, maka ketiga unsur persamaan akuntansi dinyatakan sebagai berikut [1]:

di mana:

$$
\mathrm{H}=\mathrm{U}+\mathrm{M}
$$

$\mathrm{H}=$ Harta atau aktiva

$\mathrm{U}=$ Utang atau kewajiban

$\mathrm{M}=$ Modal pemilik
Pada persamaan di atas, penggunaan utang akan menambah harta perusahaan. Tetapi harta perusahaan tersebut tidak seluruhnya menjadi hak pemilik. Karena itu, sisi kanan persamaan memisahkan utang dan modal pemilik. Dengan kata lain, bertambahnya harta perusahaan tidak selalu mencerminkan bertambahnya modal pemilik.

\section{METODE PERSEDIAAN}

Terdapat 2 metode persediaan, yaitu [3]:

\section{Sistem Perpetual}

Pada sistem perpetual, semua kenaikan dan penurunan barang dagang dicatat dengan cara yang sama dengan pencatatan kenaikan penurunan kas. Akun persediaan pada awal periode menunjukkan stok pada tanggal tersebut. Pembelian dicatat dengan mendebet persediaan barang dagang dan mengkredit kas atau utang usaha. Pada tanggal penjualan, harga pokok barang dagang yang terjual dicatat dengan mendebet harga pokok penjualan dan mengkredit persediaan barang dagang.

\section{Sistem Periodik}

Dalam metode ini, hanya pendapatan yang dicatat setiap penjualan dilakukan. Tidak ada ayat jurnal yang dibuat pada penjualan untuk mencatat harga pokok penjualan. Pada akhir periode perhitungan fisik harus dilakukan untuk menentukan biaya atau harga pokok persediaan dan harga pokok penjualan.

\section{METODE ALIRAN BIAYA PERSEDIAAN}

Terdapat tiga asumsi pencatatan aliran biaya persediaan barang dagang, yaitu [4]:

1. First-in first-out (FIFO)

Pada metode ini, barang yang pertama dibeli dianggap sebagai barang yang pertama kali pula dijual. Harga pokok barang dagang pada laporan laporan laba rugi diasumsikan adalah harga pokok barang yang dibeli pertama kali.

\section{Last-in first-out (LIFO)}

Pada metode ini, barang yang terakhir dibeli dianggap sebagai barang yang pertama kali dijual. Harga pokok barang adalah sama dengan barang yang terakhir dibeli.

3. Average

Pada metode ini, harga pokok barang dagang yang berbeda-beda tanggal pembeliannya dirata-rata untuk mendapat harga pokok yang tercatat pada laporan laba rugi. 


\section{DESAIN SISTEM}

Sebelum melakukan desain aplikasi, dilakukan survei ke beberapa usaha dagang baik yang telah terkomputerisasi maupun yang masih manual. Hasil survei digunakan sebagai pedoman dalam mendesain aplikasi yang dibutuhkan perusahaan dagang secara umum.

\section{Fitur Kustomisasi}

Dari hasil survei maka dirancang beberapa hal yang perlu untuk dikustomisasi pada saat awal penggunaan aplikasi, yaitu:

1. Menambah profil perusahaan baru yang akan menggunakan aplikasi ini dan semua datanya disimpan ke database.

2. Chart of Account. Perusahaan dapat membuat Chart of Account sendiri seperti yang telah digunakan sebelumnya. Atau perusahaan menggunakan Chart of Account yang telah tersedia.

Akun-akun yang lazim digunakan oleh perusahaan dagang, besar maupun kecil, selama masa operasinya adalah sebagai berikut:

- Akun Persediaan Barang Dagang, digunakan untuk mencatat jumlah persediaan barang dagang.

- Akun Pembelian, digunakan untuk mencatat semua transaksi pembelian barang dagang.

- Akun Retur Pembelian dan Pengurangan Harga, digunakan untuk mencatat semua transaksi pengembalian barang dagang yang dibeli dan pengurangan harga atas pengembalian barang tersebut.

- Akun Potongan Pembelian, digunakan untuk mencatat transaksi potongan pembelian.

- Akun Beban Angkut Pembelian, digunakan untuk mencatat semua transaksi pembayaran biaya angkut barang dagang yang dibeli.

- Akun Penjualan, digunakan untuk mencatat semua transaksi penjualan barang dagang.

- Akun Retur Penjualan dan Pengurangan Harga, digunakan untuk mencatat transaksi penerimaan kembali barang dagang yang telah dijual.

- Akun Potongan Penjualan, digunakan untuk mencatat transaksi potongan penjualan.

Penggunaan akun yang tersedia juga dapat diubah saat proses kustomisasi selesai.

3. Metode persediaan. Aplikasi yang dikembangkan ini menyediakan 2 macam pilihan yaitu Perpeptual dan Periodic.

4. Metode aliran biaya persediaan. Aplikasi menyediakan 3 macam pilihan yaitu FIFO, LIFO, dan Average.
5. Periode akuntansi yang digunakan. Aplikasi menyediakan 6 macam pilihan yaitu 1 bulan, 2 bulan, 3 bulan, 4 bulan, 6 bulan dan 12 bulan (1 tahun). Tanggal mulai periode akuntansi juga dapat ditentukan oleh perusahaan.

\section{Data Flow Diagram}

Untuk menggambarkan aliran data pada sistem digunakan data flow diagram (DFD). Pembuatan DFD dimulai dari context diagram yang menggambarkan garis besar proses yang terdapat pada Gambar 1.

Kesatuan terluar atau entity yang terlibat dalam sistem perusahaan dagang pada Gambar 1 secara umum ada empat yaitu: Pelanggan sebagai pihak yang membeli barang dagang, Supplier sebagai pihak yang memasok barang dagang, Gudang sebagai pihak yang mengatur barang masuk dan keluar, dan Pemilik sebagai pihak yang berkepentingan untuk mendapat laporan dari seluruh proses yang terjadi dalam usaha tersebut.

Setelah pembuatan context diagram, dilanjutkan untuk memecah penggambaran sistem menjadi bagian yang lebih detail dengan pembuatan DFD level 0 dan dapat dilihat pada Gambar 2.

Pada Gambar 2, sistem dapat dibagi dalam tiga proses besar, yaitu: kustomisasi, operasional dan akuntansi. Proses kustomisasi adalah proses yang terjadi saat pertama kali sebuah sistem dibangun. Data yang disimpan antara lain profil perusahaan, Chart $O f$ Account (akun), periode akuntansi, dan metode persediaan yang digunakan. Semua data itu nantinya akan dibutuhkan pada proses operasional dan pada proses akuntansi. Pada level ini tampak sebuah data storage dengan nama 'Database Utama' yang sebenarnya merupakan sebuah database tersendiri. Fungsi dari 'Database Utama' adalah untuk menyimpan data mengenai nama perusahaan dan nama database yang khusus digunakan oleh tiap perusahaan yang ada.

Proses operasional adalah proses yang berkaitan dengan kegiatan utama yang berlangsung dalam sebuah usaha dagang sehingga data yang diperlukan oleh sistem adalah yang berkaitan dengan Pelanggan, Supplier, Gudang dan Pemilik.

Proses akuntansi adalah proses yang menjalankan siklus akuntansi dalam usaha dagang. Aliran data yang ditunjukkan dari proses operasional ke proses akuntansi menunjukkan bahwa kegiatan penjurnalan akuntansi dilakukan secara otomatis setelah pencatatan kegiatan operasional. Proses akuntansi ini nantinya akan menghasilkan laporan jurnal dan laporan keuangan yang diberikan kepada pemilik. 


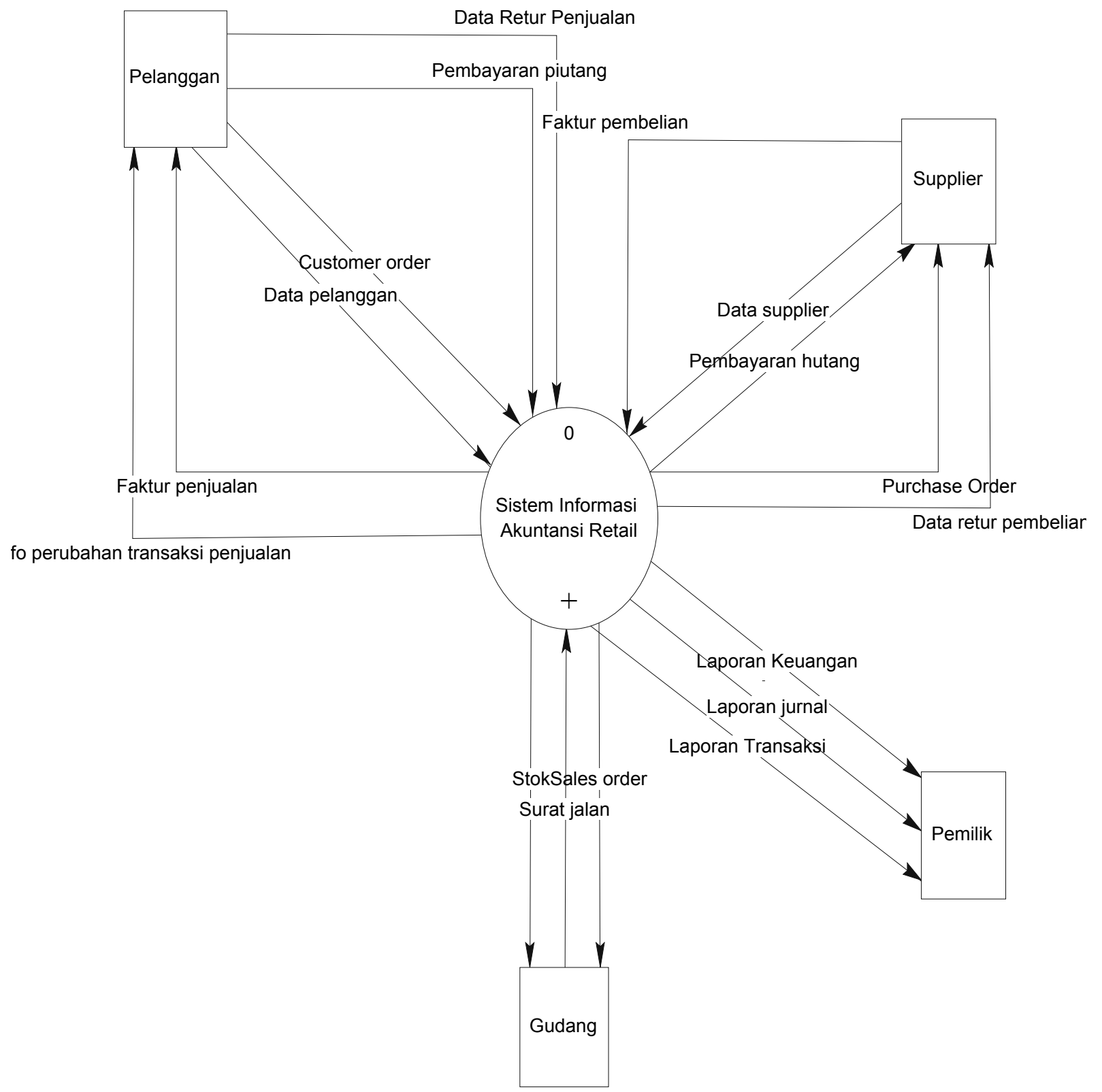

Gambar 1. Context Diagram Sistem Informasi Akuntansi 


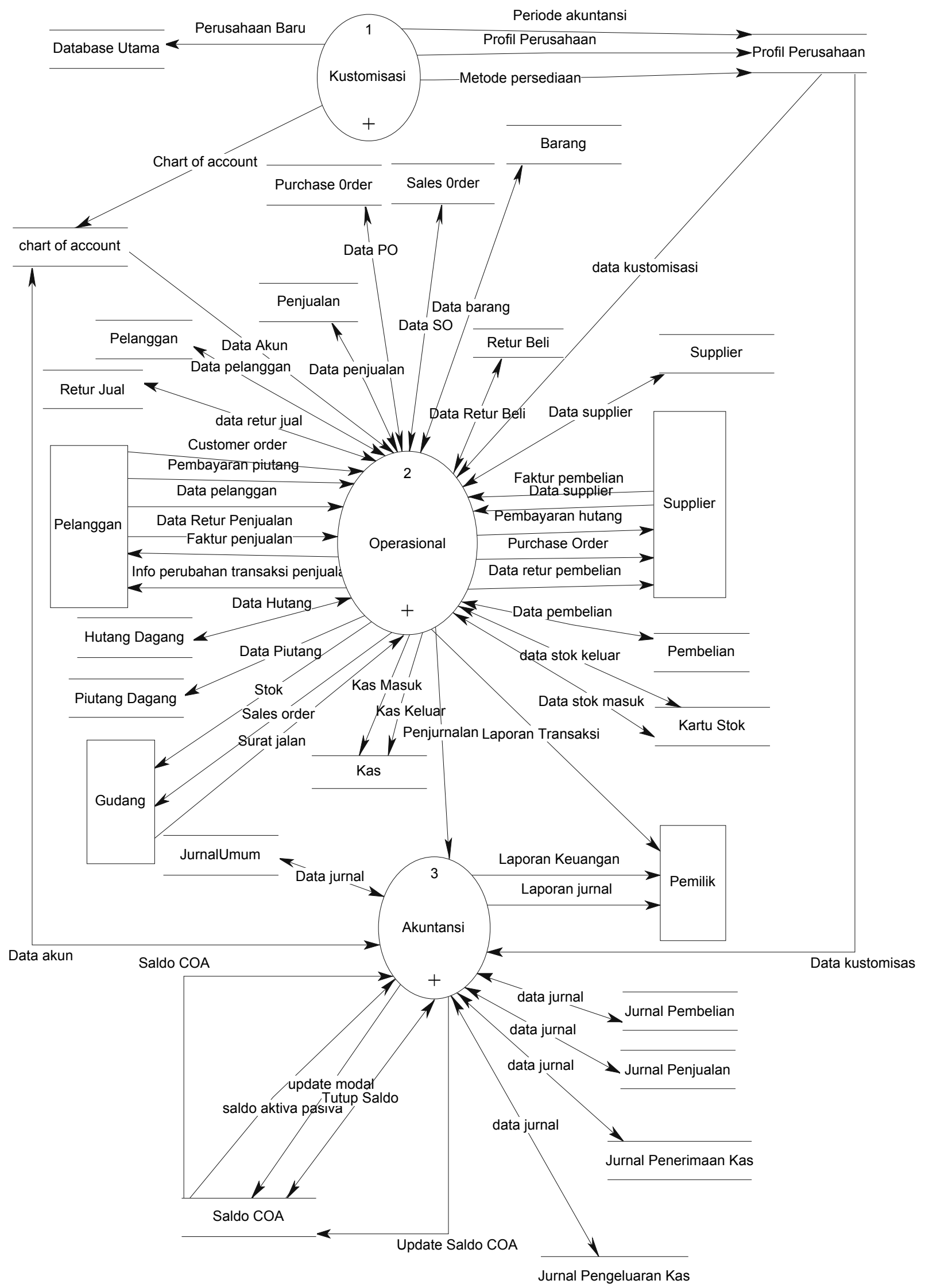

Gambar 2. DFD Level 0 Sistem Informasi Akuntansi 


\section{IMPLEMENTASI SISTEM}

Implementasi sistem dilakukan dengan menggunakan Borland Delphi 7. Sedangkan untuk database, digunakan Microsoft Access 2000. Program ini dirancang dengan menggunakan dua database yaitu, database master yang berisi data perusahaan-perusahaan yang menggunakan program ini, dan yang kedua adalah database yang berisi data milik masingmasing perusahaan. Database master ini merupakan implementasi dari storage 'Database Utama' yang terdapat pada DFD Level 0. Database master hanya terdiri dari satu tabel, yaitu tabel perusahaan yang berisi field kode perusahaan, nama perusahaan, dan nama database. Sedangkan database kedua berisi tabel-tabel yang berguna dalam menjalankan sistem informasi akuntansi ini. Nama dari database kedua ini disesuaikan dengan kode perusahaan. Ketika pertama kali membuka program, program akan terhubung ke database master. Setelah itu program akan memindahkan koneksi dari database master ke database yang kedua, sesuai dengan nama database perusahaan yang dibuka, dimana nama database tersebut tersimpan dalam database master.

Aplikasi mempunyai Form utama yang terdiri dari menu utama yaitu File, Pengaturan, Master, Transaksi, Daftar Transaksi, Tutup Buku. Masingmasing menu utama tersebut memiliki submenu. Selengkapnya dapat dilihat pada Gambar 3.

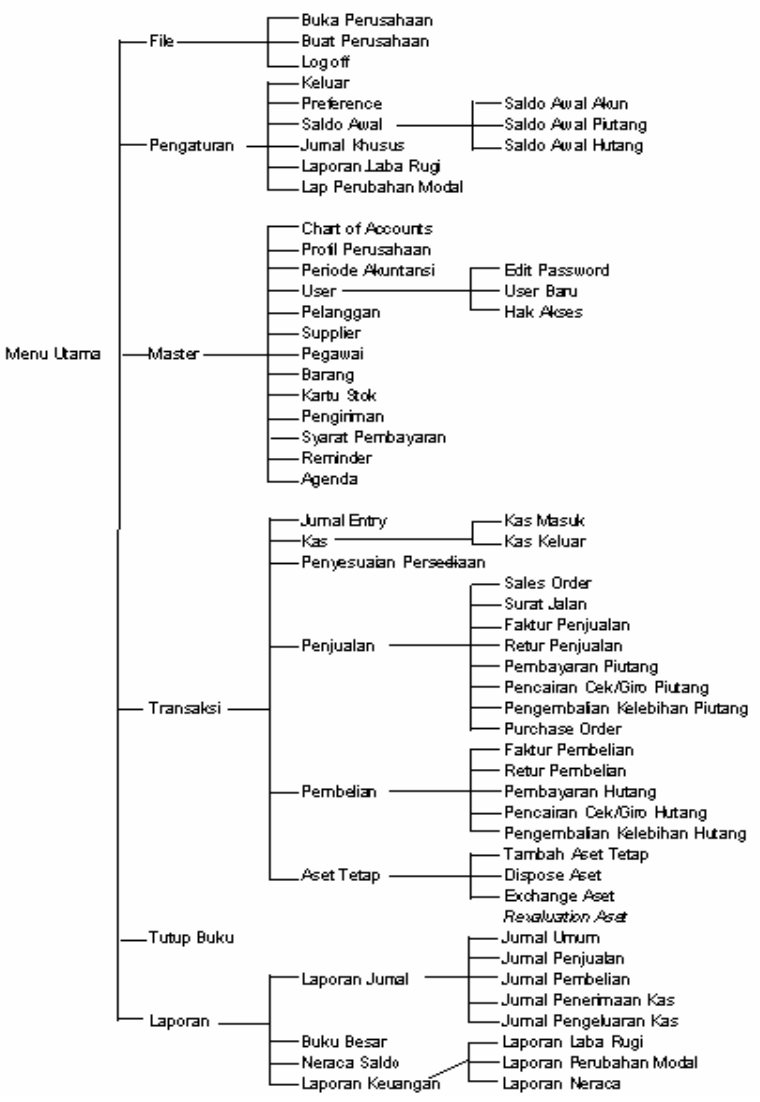

Gambar 3. Struktur Menu Aplikasi

\section{PENGUJIAN SISTEM}

Berikut ini adalah pengujian terhadap sistem yang dikembangkan. Pada saat aplikasi pertama kali dijalankan, maka pengguna akan diminta melakukan pengisian terhadap fitur kustomisasi yang disediakan. Pengisian pertama kali adalah mengenai profil perusahaan seperti terlihat pada Gambar 4.

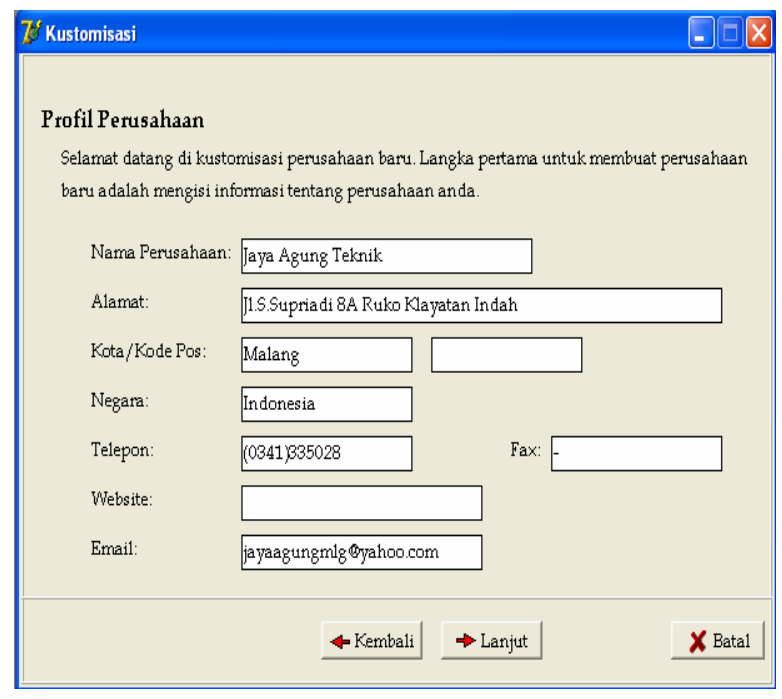

\section{Gambar 4. Pengisian Profil Perusahaan}

Pengisian berikutnya adalah rekening akun (chart of account) dimana pengguna dapat memilih untuk menggunakan rekening akun yang telah disediakan oleh aplikasi atau membuat rekening akun sendiri seperti terlihat pada Gambar 5.

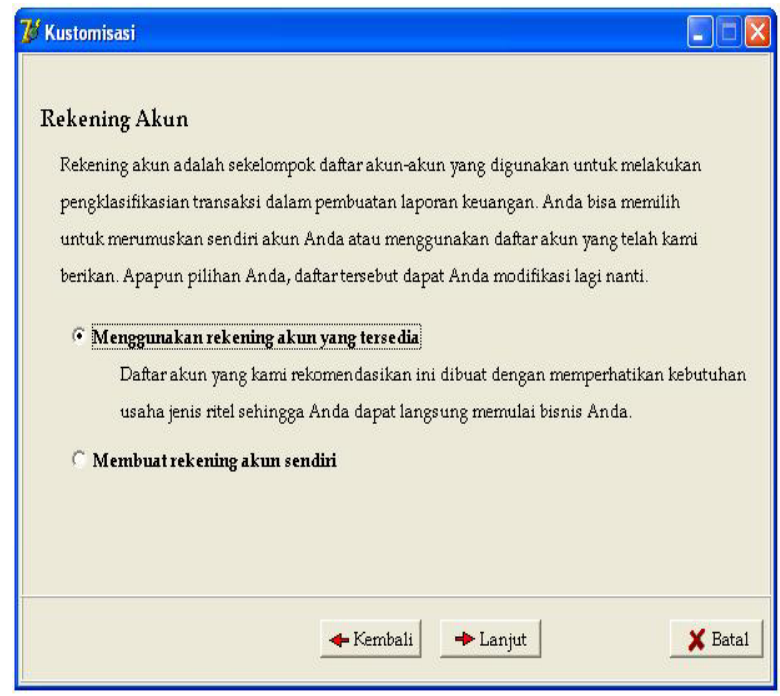

Gambar 5. Kustomisasi Rekening Akun

Pengisian fitur kustomisasi ketiga adalah pemilihan metode persediaan apakah menggunakan perpetual atau periodic. Hal ini terlihat pada Gambar 6. 


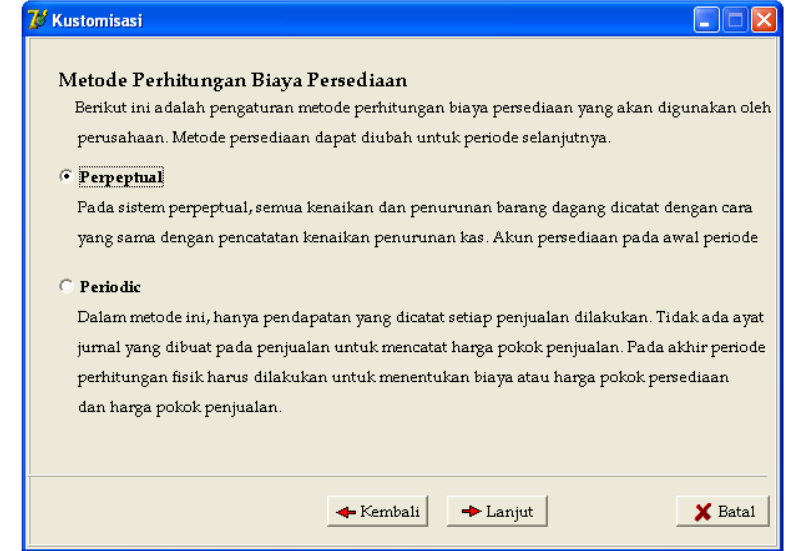

\section{Gambar 6. Pemilihan Metode Persediaan}

Langkah terakhir pada fitur kustomisasi adalah penentuan periode akuntansi seperti terlihat pada Gambar 7.

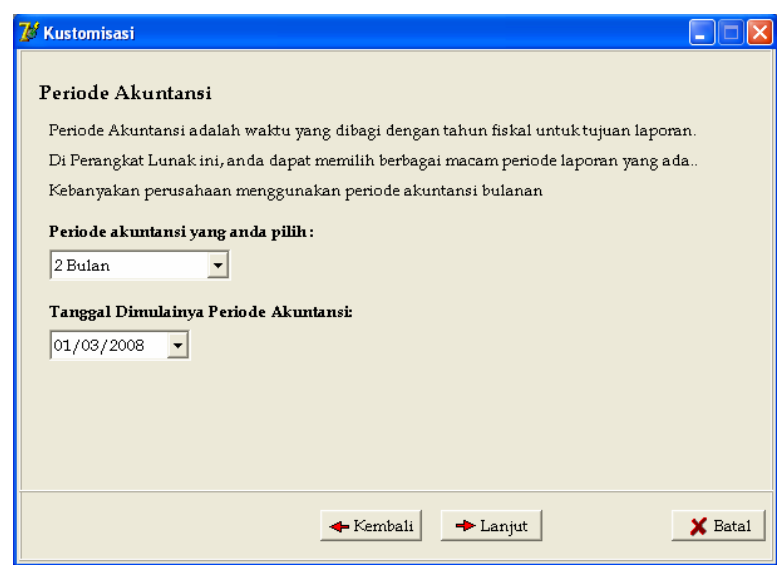

Gambar 7. Pemilihan Periode Akuntansi

Selanjutnya jika aplikasi telah digunakan dan mempunyai banyak perusahaan maka terdapat pilihan untuk melakukan pembukaan terhadap perusahaan tertentu seperti terlihat pada Gambar 8.

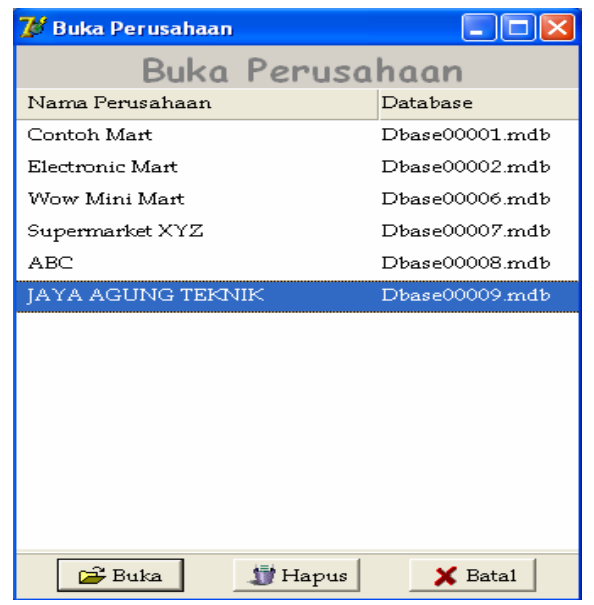

Gambar 8. Pemilihan Perusahaan
Setelah melakukan pemilihan perusahaan dan masuk ke dalam aplikasi, maka terlihat menu utama aplikasi pada Gambar 9.

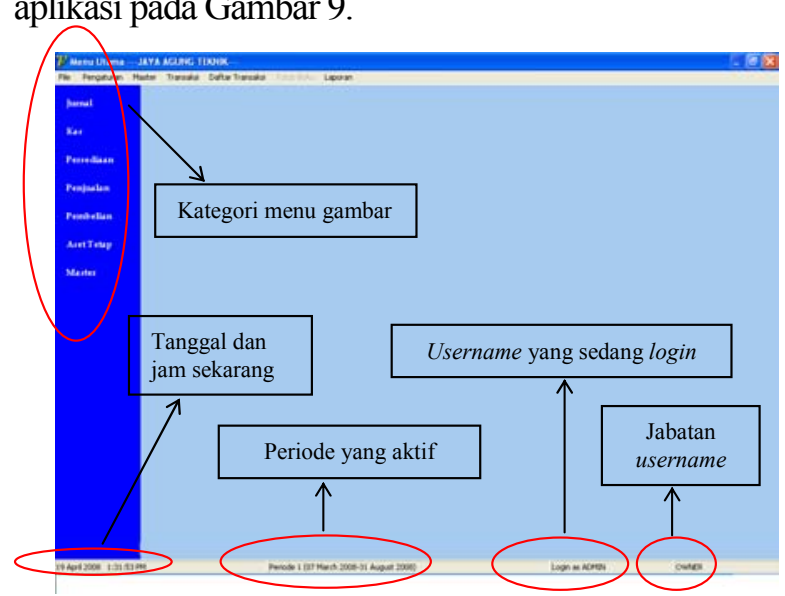

\section{Gambar 9. Menu Utama Aplikasi}

Pada saat akan melakukan transaksi pertama kali, maka perlu dilakukan pengaturan untuk rekening akun yang digunakan dalam transaksi. Pengaturan ini digunakan agar aplikasi dapat melakukan penjurnalan secara otomatis dengan benar. Hal ini terlihat pada Gambar 10.

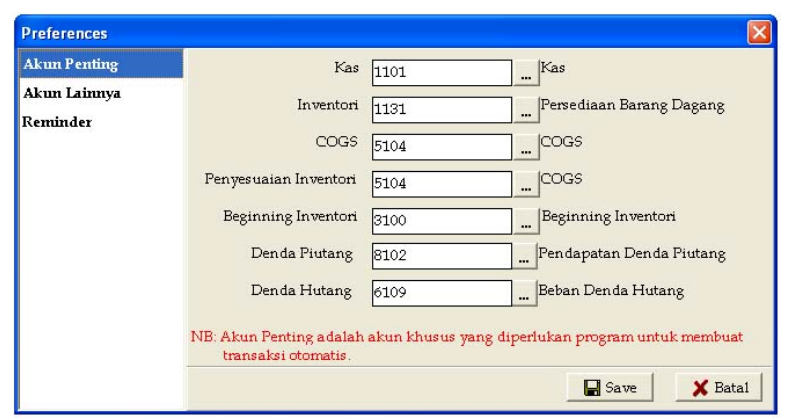

\section{Gambar 10. Pengaturan Rekening Akun}

Pengisian jenis barang dagang dapat menggunakan Form Barang seperti terlihat pada Gambar 11.

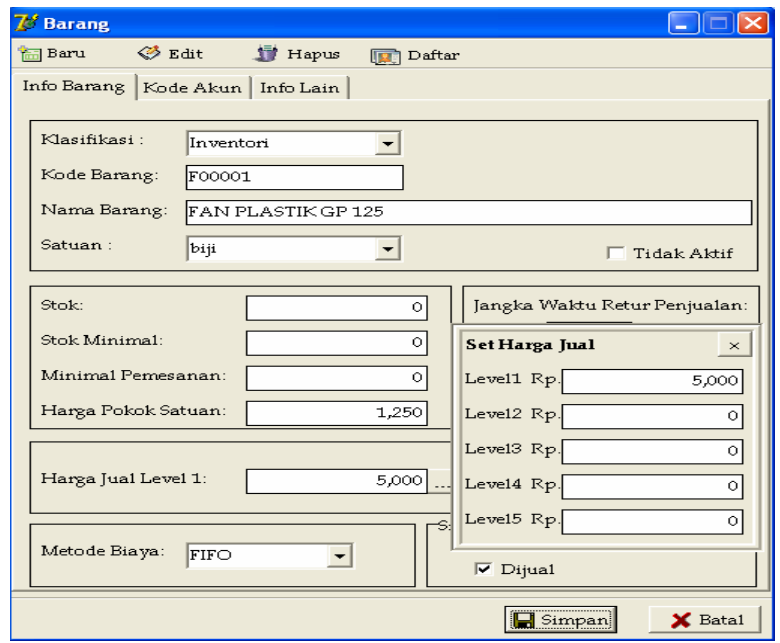

Gambar 11. Pemasukan Barang Dagang 
Pada pemasukan barang dagang ini dapat diatur metode aliran biaya persediaan barang yaitu apakah menggunakan FIFO, LIFO ataupun average, dimana metode aliran biaya persediaan ini dapat berbeda antar barang satu dengan barang lainnya. Pada kasus tersebut diatas, persediaan barang menggunakan metode FIFO.

Setelah pemasukan data jenis barang, maka dapat dilakukan transaksi sehari-hari seperti pembelian dan penjualan, pembayaran hutang dan piutang, dan lainlain. Untuk pemasukan transaksi pembelian dapat dilihat pada Gambar 12.

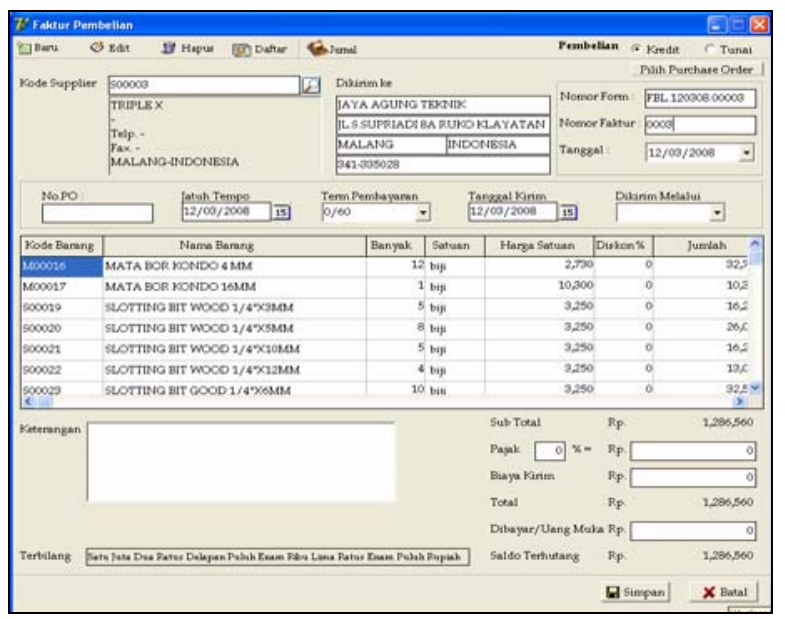

Gambar 12. Pembelian

Setelah semua transaksi dimasukkan, maka dapat dihasilkan laporan keuangan seperti laporan laba rugi, perubahan modal serta neraca. Bentuk dari laporan laba rugi dapat dilihat pada Gambar 13 serta laporan perubahan modal dan neraca dapat dilihat pada Gambar 14 dan 15.

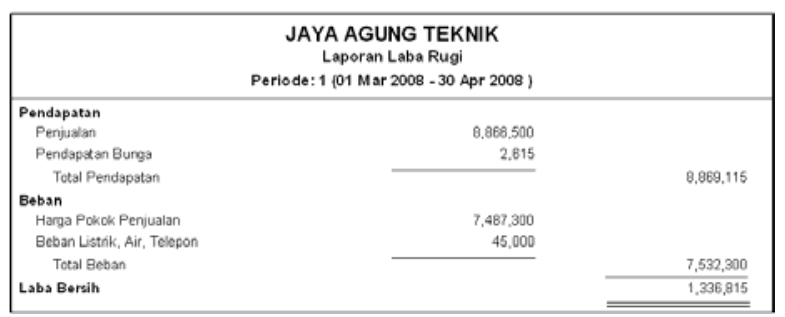

Gambar 13. Laporan Laba Rugi

\begin{tabular}{|c|c|}
\hline \multicolumn{2}{|c|}{$\begin{array}{l}\text { JAYA AGUNG TEKNIK } \\
\text { Laporan Perub ahan Modal } \\
\text { Periode : } 1 \text { (01 Mar } 2008 \text { - } 30 \text { Apr 2008) }\end{array}$} \\
\hline Modal Awal & 55.000 \\
\hline \multirow[t]{2}{*}{ Add: Laba Bersih } & $1,336,815$ \\
\hline & $1,391,815$ \\
\hline Less: Penarikan Prive & 0 \\
\hline Modal Akhir & $1,391,815$ \\
\hline
\end{tabular}

Gambar 14. Perubahan Modal

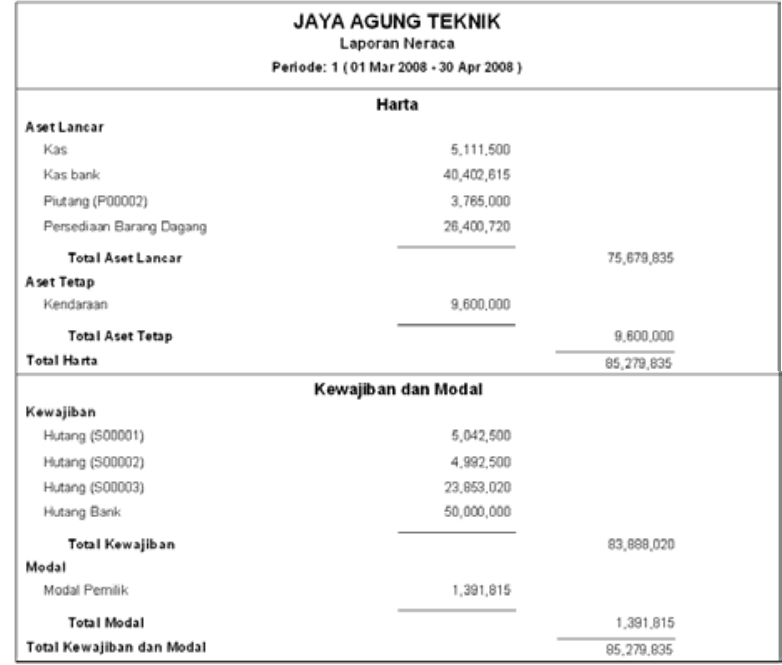

Gambar 15. Neraca

Aplikasi ini telah diujikan ke tiga perusahaan dagang dan diberikan kuisoner sebagai evaluasi ke perusahaan tersebut. Kuisoner terdiri dari 38 pertanyaan, dimana pertanyaan nomor 1-8 merupakan pertanyaan mengenai aplikasi secara keseluruhan, nomor 9-36 merupakan pertanyaan mengenai aplikasi per modul yang dibagi menjadi 10 modul, sedangkan pertanyaan nomor 37-38 merupakan pertanyaan mengenai pemenuhan kebutuhan perusahaan. Hasil dari kuesioner terdapat pada Tabel 1.

\section{Tabel 1. Hasil Pengisian Kuesioner}

\begin{tabular}{lccc}
\hline Perusahaan & $\begin{array}{c}\text { Total nilai } \\
\text { pertanya- } \\
\text { an 1-8 }\end{array}$ & $\begin{array}{c}\text { Total nilai } \\
\text { pertanya- } \\
\text { an 9-36 }\end{array}$ & $\begin{array}{c}\text { Total nilai } \\
\text { pertanya- } \\
\text { an 37-38 }\end{array}$ \\
\hline Perusahaan A & 37 & 118 & 8 \\
Perusahaan B & 33 & 114 & 6 \\
Perusahaan C & 34 & 113 & 8 \\
Nilai maksimal & $\mathbf{4 0}$ & $\mathbf{1 4 0}$ & $\mathbf{1 0}$ \\
\hline
\end{tabular}

Dari Tabel 1 tersebut dapat dihitung rata-rata nilai yang diperoleh untuk pertanyaan 1-8 adalah $87 \%$, pertanyaan 9-36 adalah $82 \%$ serta pertanyaan 37-38 adalah $73 \%$ serta rata-rata keseluruhan hasil kuesioner adalah $82 \%$.

\section{KESIMPULAN}

Kesimpulan yang dapat diambil dari keseluruhan pengerjaan penelitian ini adalah sebagai berikut:

- Perangkat lunak yang dibuat bisa mengakomodasi kebutuhan-kebutuhan utama perusahaan dagang dengan nilai cukup pada perusahaan yang diuji.

- Penilaian untuk tingkat user interface mendapat nilai cukup pada perusahaan yang diuji sehingga bisa disimpulkan perangkat lunak yang dibuat bisa dimengerti dan dijalankan oleh user dengan cukup mudah. 
Dari hasil kuisioner diperoleh persentase sebesar 87\% untuk kemudahan aplikasi secara keseluruhan, $82 \%$ untuk kemudahan dan ketepatan aplikasi per modul dan $73 \%$ tercapainya pemenuhan kebutuhan perusahaan.

\section{DAFTAR PUSTAKA}

1. Kieso, Kimmel, and Weygandt. Accounting Principles, 7th Edition, United State of America: John Wiley \& Sons Inc, 2005.
2. Cushing, Barry E., Marshall B. Romney, and Paul J. Steibart, Accounting Informaton System, USA: Addision-Wesley Publishing Company Inc, 2004.

3. Niswonger, Warren, Reeve, and Fees. Prinsipprinsip Akuntansi Jilid 1, edisi 19, Jakarta: Erlangga, 1999.

4. Marshall B. Romney, Accounting Information System, 8th Edition, USA: Prentice Hall, 2002. 